ZESZYTY NAUKOWE UNIWERSYTETU SZCZECIŃSKIEGO

NR 884

EKONOMICZNE PROBLEMY USŁUG NR 119

2015

DOI: 10.18276/epu.2015.119-10

\author{
Anna Tomová* \\ Ivana Kirschnerová**
}

\title{
THE PLAYERS IN AIRPORT GROUND HANDLING: A NEW TYPOLOGY REFLECTING THE INTERNATIONAL EXPANSION ${ }^{1}$
}

\begin{abstract}
The paper deals with the global nature of some players in airport ground handling industry. We provide a comprehensive overview of factors that cause fragmentation in the ground handling industry to explain the context in which global players develop their business internationally. Using the modified versions of UNCTAD Geographical Spread Indices we investigate several ground handlers and design a new typology of ground handlers according to their international expansion: key global ground handlers, key interregional international ground, key international intraregional ground handlers and locally important handlers. Adding the dimension of product portfolio we create a twodimensional grid enabling to analyse evolution of ground handling industry to reflect international expansion of key players in different ground handling services. Arguing via the organic growth and consolidation examples, we assume the shift of the industry towards multiproduct ground handling companies with extensive international presence in all world regions.
\end{abstract}

* Anna Tomová, Associate professor, PhD, University of Žilina, Faculty of Operation and Economics of Transport and Communications, e-mail address: anna.tomova@fpedas.uniza.sk.

** Ivana Kirschnerová, Ing., University of Žilina, Faculty of Operation and Economics of Transport and Communications, e-mail address: ivana.kirschnerova@fpedas.uniza.sk.

1 Supported by Project KEGA MŠ SR 024 ŽU-4/2014. 
Keywords: ground handling; airport; liberalisation; deregulation; geographical spread, product portfolio, international expansion

\section{Introduction}

The ground handling carried out for airlines at the airport covers a complex of miscellaneous aviation-related activities inevitable for the operation of air services such as ramp handling, baggage handling, passenger handling, cargo and mail handling, etc. At present, global ground handling market is estimated to generate about 50 billion USD annually (Airline Ground Services, 2014). The supply side of ground handling business is represented by manyplayers which are in principle airports as ground handlers, airlines as self-handlers, airlines as third party ground handling suppliers, and independent ground handling companies. Some of the independent ground handling companies have been mentioned in the global context in the papers of Müller et al. (2008), Burghouwt et al. (2014: 56-63) and Meersman et al. (2011: 123-135). According to the state of our knowledge, the only WTO study (World Trade Organisation 2007) focused more on the global nature of key ground handling players, however, it used only several simple characteristics to provide some evidence (number of airports served by handlers, number of countries with the handlers' presence, revenues and turnover data). The study covered seventeen independent ground handlers in 2000 and 2004/2005, or the year 2005 year respectively. Ten years later, a more systematic approach to the topic has still been lacking.

In the paper we provide a comprehensive overview of factors that cause fragmentation in the ground handling industry to explain context in which global players develop their business internationally. The current academic literature does not deal with the issue in such a complex way. Then we provide a quantitative evidence about the global scope of the ground handlers business. For this purpose, we use the modified versions of UNCTAD geographical spread index. Consequently, we develop a new typology of independent ground handlers based on two dimensions and finally, we discuss why the global nature of key players will be reinforced in future. 


\section{Fragmentation of ground handling markets}

The fragmented nature of ground handling is driven by mosaics of ground handling services, mosaics of market structures even at the airport level, mosaics of regulatory measures both on national and international level including ownerships and management issues.

\section{Mosaics of ground handling services}

The mosaics of ground handling markets is primarily given by the mosaics of ground handling services at an airport, i.e. when an issue is locally considered. Different ground handling services at the airport may be delivered under various regulatory regimes (more or less liberalized) with regard to the number of suppliers, nature of suppliers and overall market structure. Therefore, the local ground handling market even at a specific airport can be represented by a mosaic of different ground handling markets according to specific ground handling services. Countries use manifold approaches to the categorizations of ground handling services in operational practice and regulatory legislation. The ICAO Airport Economics Manual (International Civil Aviation Organisation 2013) separates ground handling functions into terminal handling and apron handling. International Ground Handling Council of IATA splits ground handling in the eight following categories: ramp services, passenger services, representation, administration and supervision, load control, communication and flight operation, cargo and mail, aircraft maintenance and security. For the purposes of deregulation of ground handling markets at European airports, ground handling services are covered by the eleven categories as contained in Table 1 .

Table 1. Overview of non-self ground handling suppliers at Côte d'Azur airport in 2014 according to services

\begin{tabular}{|c|l|c|}
\hline Ground handling services & \multicolumn{1}{|c|}{ Non-self suppliers of the services } & $\begin{array}{c}\text { Number of } \\
\text { non-self } \\
\text { suppliers }\end{array}$ \\
\hline 1 & \multicolumn{1}{|c|}{2} & 3 \\
\hline $\begin{array}{c}\text { 1. Ground administration } \\
\text { and supervision services }\end{array}$ & $\begin{array}{l}\text { AIR FRANCE, AIR ROUTING INTERNATIONAL, AVIA- } \\
\text { PARTNER NICE, BRINK'S EVOLUTION, CANONICA, } \\
\text { ENCORE MAP, G OPS, HELI AIR MONACO, ICTS, MAP } \\
\text { HANDLING NICE, PREMIER CATERING, SWISSPORT } \\
\text { EXECUTIVE, SWISSPORT NICE, N.C.L., S.P.A.C.E (N.C.L. } \\
\text { and S.P.A.C.E. except loading unit processing, storage, han- } \\
\text { dling and administration) }\end{array}$ & 15 \\
\hline
\end{tabular}




\begin{tabular}{|c|c|c|}
\hline 1 & 2 & 3 \\
\hline 2. Passenger handling & $\begin{array}{l}\text { AIR FRANCE, AVIAPARTNER NICE, ENCORE MAP, HELI } \\
\text { AIR MONACO, HELI SECURITE, ICTS, MAP HANDLING } \\
\text { NICE, SAMSIC APMR PACA, SWISSPORT EXECUTIVE, } \\
\text { SWISSPORT NICE }\end{array}$ & 10 \\
\hline 3. Baggage handling & $\begin{array}{l}\text { AIR FRANCE, AVIAPARTNER NICE, ENCORE MAP, HELI } \\
\text { AIR MONACO, MAP HANDLING NICE, SWISSPORT } \\
\text { EXECUTIVE, SWISSPORT NICE }\end{array}$ & 7 \\
\hline 4. Cargo and mail handling & $\begin{array}{l}\text { AIR FRANCE, AVIAPARTNER NICE, FRANCE HAN- } \\
\text { DLING, HELI AIR MONACO, MAP HANDLING NICE, } \\
\text { SWISSPORT CARGO SERVICES, SWISSPORT EXECUTI- } \\
\text { VE, SWISSPORT NICE, BRINK'S EVOLUTION, CHRONO- } \\
\text { POST (BRINK'S EVOLUTION and CHRONOPOST except } \\
\text { supervision of loading, messages and telecommunications) }\end{array}$ & 11 \\
\hline 5. Ramp handling services & $\begin{array}{l}\text { AIR FRANCE, ENCORE MAP, HELIAIR MONACO, MAP } \\
\text { HANDLING NICE, SWISSPORT EXECUTIVE, SWIS- } \\
\text { SPORT NICE } \\
\text { Only loading and unloading of aircraft, including the supply } \\
\text { and implementation of appropriate resources, transporting } \\
\text { the crew and passengers between the aircraft and the terminal } \\
\text { building, and transporting baggage between the aircraft and the } \\
\text { terminal building: BRINK'S EVOLUTION, HELI SECU- } \\
\text { RITE, IDEM MULTISERVICES, VEOLIA TRANSPORT } \\
\text { ALPES MARITIMES. } \\
\text { Only transporting food and beverages to the aircraft, loading } \\
\text { them onto the aircraft and unloading them from the aircraft: } \\
\text { CANONICA, CLEAN JET AZUR, EXCLUSIVE CATERING, } \\
\text { N.C.L., PREMIER CATERING, SIP NETTOYAGE }\end{array}$ & 16 \\
\hline $\begin{array}{l}\text { 6. Aircraft cleaning } \\
\text { services }\end{array}$ & $\begin{array}{l}\text { AIR FRANCE, AVIAPARTNER NICE, NECORE MAP, EX- } \\
\text { CLUSIVE CATERING, GSF JUPITER, HELI AIR MONA- } \\
\text { CO, MAP HANDLING NICE, SWISSPORT EXECUTIVE, } \\
\text { SWISSPORT NICE. } \\
\text { Only aircraft interior and exterior cleaning, toilet servicing and } \\
\text { water supply servicing CLEAN JET AZUR, N.C.L., NET FLY } \\
\text { NICE, SIP NETTOYAGE, SKY NET ASSISTANCE } \\
\end{array}$ & 14 \\
\hline $\begin{array}{l}\text { 7. Fuel and oil handling } \\
\text { services }\end{array}$ & $\begin{array}{l}\text { BP FRANCE, ENCORE MAP, FUELING PARTNER, HELI } \\
\text { AIR MONACO, SASCA, SKYTANKING NICE, SWIS- } \\
\text { SPORT EXECUTIVE, TOTAL } \\
\text { Only organising and providing fueling and defueling services, } \\
\text { including storage and fuel supply quality control: ESSO, HELI } \\
\text { SECURITE. } \\
\text { Only topping up oil and other fluid levels: AAS AIR- } \\
\text { SUPPORT, AIR FRANCE, AWAC TECHNICS, CESSNA } \\
\text { CITATION EUROPEAN SERVICE CENTER (CCESC), MAP } \\
\text { HANDLING NICE, NAYAK AIRCRAFT SERVICES ITALY, } \\
\text { SRL, SWISSPORT NICE }\end{array}$ & 18 \\
\hline $\begin{array}{l}\text { 8. Aircraft maintenance } \\
\text { services }\end{array}$ & $\begin{array}{l}\text { AAS AIRSUPPORT, AIR FRANCE, AWAC TECHNICS, } \\
\text { ESSNA CITATION EUROPEAN CENTER (CCESC) DERI- } \\
\text { CHEBOURG ATIS MAINTENANCE SERVICES, NAYAK } \\
\text { AIRCRAFT SERVICES ITALY SRL, SWISSPORT EXECU- } \\
\text { TIVE, TURKISH AIRLINES. }\end{array}$ & 8 \\
\hline $\begin{array}{l}\text { 9. Flight operation and } \\
\text { crew administration } \\
\text { services }\end{array}$ & $\begin{array}{l}\text { AIR FRANCE, AIR ROUTING INTERNATIONAL, AVIA- } \\
\text { PARTNER NICE, ENCORE MAP, MAP HANDLING NICE, } \\
\text { SWISSPORT EXECUTIVE, SWISSPORT NICE }\end{array}$ & 7 \\
\hline
\end{tabular}




\begin{tabular}{|c|l|l|}
\hline \multicolumn{1}{|c|}{1} & \multicolumn{1}{|c|}{2} & \\
\hline $\begin{array}{c}\text { 10. Ground transport } \\
\text { services }\end{array}$ & $\begin{array}{l}\text { AIR FRANCE, AIR ROUTING INTERNATIONAL, AVIA- } \\
\text { PARTNER NICE, BRINK'S EVOLUTION, ENCORE MAP, } \\
\text { MAP HANDLING NICE, RIVIERA BAGAGES EXPRESS, } \\
\text { SWISSPORT EXECUTIVE, SWISSPORT NICE } \\
\text { Only the organisation and provision of transport for passen- } \\
\text { gers, crew, baggage, cargo and mail between terminal buildings } \\
\text { of the same airport, excluding any transport between the } \\
\text { aircraft and any other point within the perimeter at the same } \\
\text { airport: HELI SECURITE } \\
\text { Only all special transport arrangements requested by the car- } \\
\text { rier: COLITEL, N.C.L., SKYROAD }\end{array}$ & 13 \\
\hline 11. Aircraft catering & $\begin{array}{l}\text { AIR FRANCE, AVIAPARTNER NICE, CANONICA, EN- } \\
\text { CORE MAP, EXCLUSIVE CATERING, N.C.L., PREMIER } \\
\text { CATERING, SWISSPORT EXECUTIVE, SWISSPORT NICE } \\
\text { Only liaising with suppliers and administrative management: } \\
\text { MAP HANDLING NICE } \\
\text { Only storage of food, beverages and the catering equipment } \\
\text { required to prepare them:CLEAN JET AZUR }\end{array}$ & 11 \\
\hline
\end{tabular}

Source: Aeroport Nice. Ground Handling Services. http://btob.nice.aeroport.fr/Professionals/AIRLINES-SERVICES/Ground-Assistance/Ground-handling-categories.

\section{Mosaics of market structures}

The fragmented nature of ground handling is given also by mosaics of market structure. In principle, there are three generic models of market structures for any category of ground handling services. In the centralized model, the airport is a monopolistic supplier of ground handling services without a freedom for selfhandling by airlines and handling by other than the airport third party suppliers (other airlines, independent handling companies). In the self-handling model, only airlines as self-handlers provide ground services for themselves, thus there is no other supplier of the services, neither the airport nor independent ground handling companies, nor airlines as third party suppliers for other airlines. In the model of independent handling, neither self-handling nor handling by the airport itself is allowed accessing thus the ground handling markets only for independent ground handling companies. In practice, the generic models are differently mixed according to the de/regulation rules. 


\section{De/regulation of domestic markets}

Some ground handling markets at airports are still monopolistic or duopolistic, others are more or less deregulated. The deregulation of ground handling markets is executed via implementing two access freedoms - the freedom of self-handling and the freedom of third-party handling.

In the EU, ground handling markets at airports have been gradually deregulated by the European Union Council Directive 96/67/EC introducing the two above mentioned ground handling liberties. In principle, the member countries could opt between the liberal or restricted regimes for self-handling and third-party handling at airports with more than two million passengers per year or 50,000 tons of freight for four ground handling services (fuel and oil, ramp handling, baggage handling, freight and mail handling) letting the other ground handling markets freely open without any restriction in market access for self-handlers and third party handlers at such airports. With regard to the airports under the size threshold, free self-handling has been required by the directive, however, not covering anyhow third party handling at smaller airports. The market access to restricted ground handling services at the EU airports has been governed by national regulatory rules requiring a tender procedure. As different EU member countries differently applied the Directive 96/67/EC, the current market with ground handling services in the EU is still fragmented with regard to the level of liberalism introduced in the delivery of ground handling services by countries at EU airports. Due to the introduction of the directive, the deregulation has increased a number of suppliers on ground handling markets thus enabling a better choice for airlines at EU airports (ACR 2009). While prior to the ground handling Directive $96 / 97 / \mathrm{EC}$, only $7 \%$ of ground handling was undertaken by independent handlers, the liberalisation of the market opened up by the Directive has risen the share of independent handlers to $45 \%$ (CAPA 2014). This was fully in line with the objective of efficient markets with ground handling services for the airlines competing on a single and liberalised market with the air services within the EU. The recent proposal for a new ground handling regulation liberalising ground handling in the EU has been withdrawn by the new European Commission (European Commission 2014).

Contrary to the EU, in the US few large hub airports provide ground handling services for their customers and only several airports in the US restrict the number of ground handlers. Due to the consolidation of airlines and chan- 
ging network strategy of airlines, certain small airports in the US have started providing ground handling services themselves thus raising a discussion about the competition of private entities (airlines and independent ground handlers) and publicly owned airports on markets with ground handling services (NATA 2014). In 2007, ground handling regulation in India (motivated mainly by security issues) restricted a number of ground handlers at six metropolitan airports limiting in this way access to ground handling markets and subsequently the level of competition (Paulus 2011). In accordance with the new ground handling policy expected in India, the Indian airlines would have to outsource all ground handling to an authorised provider and thus the market for third party providers would be significantly larger (CAPA 2014). The limitations on a number of ground handling suppliers still exist in many countries, like in Chile and Colombia, whereas in Paraguay apart from the limitations on the number of service suppliers in ground handling, DINAC (National Directorate of Civil Aviation) is the only entity authorized to provide the ramp handling services at the airports in the country (Results of the Public Survey on the Trade in Services Agreement 2014). In Russia, the monopolistic provision of ground handling services prevails and is recognized as one of the industry's major problem together with a lack of specific legal regulation for ground hand-ling (Gerden 2014). From this point of view, the global ground handling industry manifests as the mosaics of different ground handling markets under different regulatory policies of countries.

\section{Regulatory policies towards foreign airlines}

The mosaic nature of ground handling markets is reinforced also by specific regulatory policies towards foreign airlines. In general, the international air transportation (and access of foreign airlines to the territory of states) is governed by bilateral and plurilateral air service agreements between states. Some of the agreements contain the specific ground handling clause stating options in the delivery of ground handling services for foreign airlines at accessed airports in a foreign territory regularly on the basis of reciprocity. Three options are recommended by ICAO (International Civil Aviation Organisation 2009) in its air service agreement template - traditional, transitional and fully liberal. When agreed upon the fully liberal ground handling clause, foreign airlines would be allowed to be self-handled, select among competing ground handlers at foreign airports but even handle other carriers and also join with others in forming a service- 
providing entity at foreign airports. Traditionally, back in the era of the regulated markets with air services national airlines and/or airports were designed as the exclusive ground handlers for foreign airlines. At present, this regime is still in force in several countries even after the liberalisation of domestic markets with air services. In Bangladesh, the Biman Bangladesh Airlines is approved by the regulatory body as the sole ground handler at all airports within the country to handle all foreign carrier flights operated on commercial basis. In this way, the historical "flag carrier" can be supported in competition with new airlines which have entered the market with air services due to the liberalisation. When markets with the ground handling service are more open due to the deregulation, some further limitations can still exit such as ownership, control and managerial barriers for new entrants.

\section{Ownership aspects of regulation}

In Turkey, foreigners are not allowed to set up a ground handling company in full foreign ownership and minimum $51 \%$ of the shares must belong to Turkish citizens (Savaser 2014). According to the Results of the Public Survey on the Trade in Services Agreement (Results of the Public Survey on the Trade in Services Agreement 2014) there are legal limitations for foreign capital, the limit to management control and residency or nationality requirements for senior management and board of directors in ground handling in Australia, Canada, Chile and Panama while in Mexico the provision of ground handling services is reserved solely for Mexican nationals.

\section{Research questions}

The research of the ground handlers which expand their business internationally across the mosaics still lacks in a more consistent approach. To fill the research gap we have been motivated by the following research questions:

- how can the international expansion of key ground handling players be identified by a quantitative way to follow the process in the long term?,

- could the WTO approach to the ground handlers' typology according to their international presence be innovated (and better for the research and regulatory policies)?,

- which evolution direction of the ground handling industry can be expected in future and how a new typology can be useful in this respect? 


\section{Data and methodology}

In order to map the global nature of the ground handler business we have used the Geographical Spread Index (GSI) of UNCTAD which is a standard tool for analysing transnational corporations (United Nations Conference on Trade and Development 2009). We have applied two ground handling versions of the GSI. The GSI1 works with a number of airports (all airports and the foreign ones) and a number of relevant foreign (host) countries at which a handler operates, while the GSI2 works with airports in foreign world regions and a number of foreign world regions in line with the following formulas:

$$
G S I_{1}=\sqrt{I I_{1} \cdot n_{c 1}}
$$

where:

$I I_{1} \quad$ - internationalization index computed as the ratio of a number of airports in foreign countries and total number of airports at which a ground handler operates,

$n_{\mathrm{c} 1}-$ number of foreign countries at which a ground handler operates.

$$
G S I_{2}=\sqrt{I I_{2} \cdot n_{c 2}}
$$

where:

$\mathrm{II}_{2}$ - internationalization index computed as the ratio of a number of airports in foreign world regions and the total number of airports at which a ground handler operates,

$n_{\mathrm{c} 2}-$ number of foreign world regions at which ground handler operates.

We have computed the 2014 GSIs for the ground handlers analysed in the WTO (5), but due to the acquisitions and mergers within the industry as well as capabilities of the IATA IGHC database, the original list of seventeen global ground handlers covered by the WT0 (5) study is therefore narrower. The results of the computed GSIc have enabled us to construct a new typology of ground handling players according to their international expansion. Consequently, we have developed the two-dimensional grid which describes the ground handling industry in their international movement and product portfolio. 


\section{Results}

The results of the GSIs gathered in Tables 2 and 3 have led us to a more consistent typology of ground handling players in comparison with the approach of WTO.

Table 2. Share of airports in world regions of selected ground handling companies

\begin{tabular}{|l|c|c|c|c|c|c|c|c|c|c|}
\hline \multirow{2}{*}{$\begin{array}{l}\text { Ground handling } \\
\text { company }\end{array}$} & \multirow{2}{*}{ Headquarter } & \multirow{2}{*}{$\begin{array}{c}\text { Number of } \\
\text { ecuntries }\end{array}$} & $\begin{array}{c}\text { Number of } \\
\text { airports }\end{array}$ & Europe & $\begin{array}{c}\text { North } \\
\text { America }\end{array}$ & $\begin{array}{c}\text { South } \\
\text { America }\end{array}$ & Asia & Africa & Middle Eust & $\begin{array}{c}\text { Australia } \\
\text { and Oceania }\end{array}$ \\
\hline Swissport & Switzerland & 35 & 174 & $34 \%$ & $36 \%$ & $13 \%$ & $3 \%$ & $11 \%$ & $2 \%$ & $0 \%$ \\
\hline Menzies Aviation & UK & 25 & 115 & $31 \%$ & $41 \%$ & $10 \%$ & $4 \%$ & $7 \%$ & $0 \%$ & $6 \%$ \\
\hline ASIG & UK & 6 & 67 & $21 \%$ & $78 \%$ & $0 \%$ & $1 \%$ & $0 \%$ & $0 \%$ & $0 \%$ \\
\hline Celebi & Turkey & 5 & 33 & $6 \%$ & $0 \%$ & $3 \%$ & $91 \%$ & $0 \%$ & $0 \%$ & $0 \%$ \\
\hline dnata & UAE & 5 & 15 & $27 \%$ & $0 \%$ & $0 \%$ & $27 \%$ & $0 \%$ & $7 \%$ & $40 \%$ \\
\hline SATS & Singapur & 9 & 10 & $0 \%$ & $0 \%$ & $0 \%$ & $100 \%$ & $0 \%$ & $0 \%$ & $0 \%$ \\
\hline Acciona Airport Services & Spain & 3 & 9 & $100 \%$ & $0 \%$ & $0 \%$ & $0 \%$ & $0 \%$ & $0 \%$ & $0 \%$ \\
\hline Airport Terminal Services & USA & 1 & 24 & $0 \%$ & $100 \%$ & $0 \%$ & $0 \%$ & $0 \%$ & $0 \%$ & $0 \%$ \\
\hline
\end{tabular}

Source: the authors, according to the IATA IGHC database.

Table 3. Global spread of selected ground handling companies as of October 2014 according to the IATA IGHC database

\begin{tabular}{|l|c|c|c|c|}
\hline Ground handling company & $\mathbf{I I}_{\mathbf{1}}$ & $\mathbf{G S I}_{\mathbf{1}}$ & $\mathbf{I I}_{\mathbf{2}}$ & $\mathbf{G S I}_{\mathbf{2}}$ \\
\hline Swissport & 0,983 & 5,780 & 0,661 & 1,818 \\
\hline Menzies Aviation & 0,896 & 4,636 & 0,687 & 1,853 \\
\hline ASIG & 0,821 & 2,026 & 0,791 & 1,258 \\
\hline Celebi & 0,152 & 0,778 & 0,091 & 0,426 \\
\hline dnata & 0,933 & 1,932 & 0,933 & 1,673 \\
\hline SATS & 0,900 & 2,683 & 0 & 0 \\
\hline Acciona Airport Services & 0,556 & 1,054 & 0 & 0 \\
\hline Airport Terminal Services & 0 & 0 & 0 & 0 \\
\hline
\end{tabular}

Source: own computation. 
In this typology we distinguish:

- key global ground handlers with geographical spread of their operation in all world regions $\left(\mathrm{GSI}_{2}\right)$,

- key interregional international ground handlers with geographical spread of their operation in more than one world regions but not at all,

- key international intraregional ground handlers with zero values of $\mathrm{GSI}_{2}$, however with high values of GSI,

- locally important players identified through a number of airports operated within a country.

Using the new typology, Swissport and Menzies Aviation, as two biggest players in the industry, differ. While Swissport has achieved the highest values of $\mathrm{II}_{1}$ and $\mathrm{GSI}_{1}$, Menzies Aviation has been ranked as the most globalised ground handler by the values of $\mathrm{II}_{2}$ and $\mathrm{GSI}_{2}$. ASIG, Celebi and dnata have been identified as key interregional international players. SATS and Acciona Airport Services, with zero values of II $_{2}$ and GSI $_{2}$ but with the interesting values of II $_{1}$ and GSI $_{1}$, have been labelled as key international intraregional players within one world region. Airport Terminal Services, due to the number of airports at which it delivers ground handling services, has been identified as a locally important player although the size of the country may influence the relevancy of such a typology.

As independent ground handling companies have different product portfolios in their supply, we have added to our analyses the categories of ground handling services in line with the IATA IGHC database. According to our findings, Menzies Aviation has not included the security services in its portfolio, while Swissport has expanded by full-range the ground handling services according to the categories of services although not in all airports within its network. Within a group of key interregional international players dnata has had at disposal the full-range supply of services according to the categories by which cargo and mail services have been delivered at all dnata network of airports. Within the group Celebi has not provided the aircraft maintenance on its network similarly as ASIG which has even delivered services within seven categories at all its airports. SATS, as an international intraregional handler, has expanded by one complete portfolio covering all categories of services while Acciona Airport Services has not included in its product portfolio the aircraft maintenance. Airport Terminal Services as locally important ground handler have provided services covered by two categories of ground handling on all airports within its network. Using 
both the product portfolio and the geographical spread, we have created the twodimensional grid.

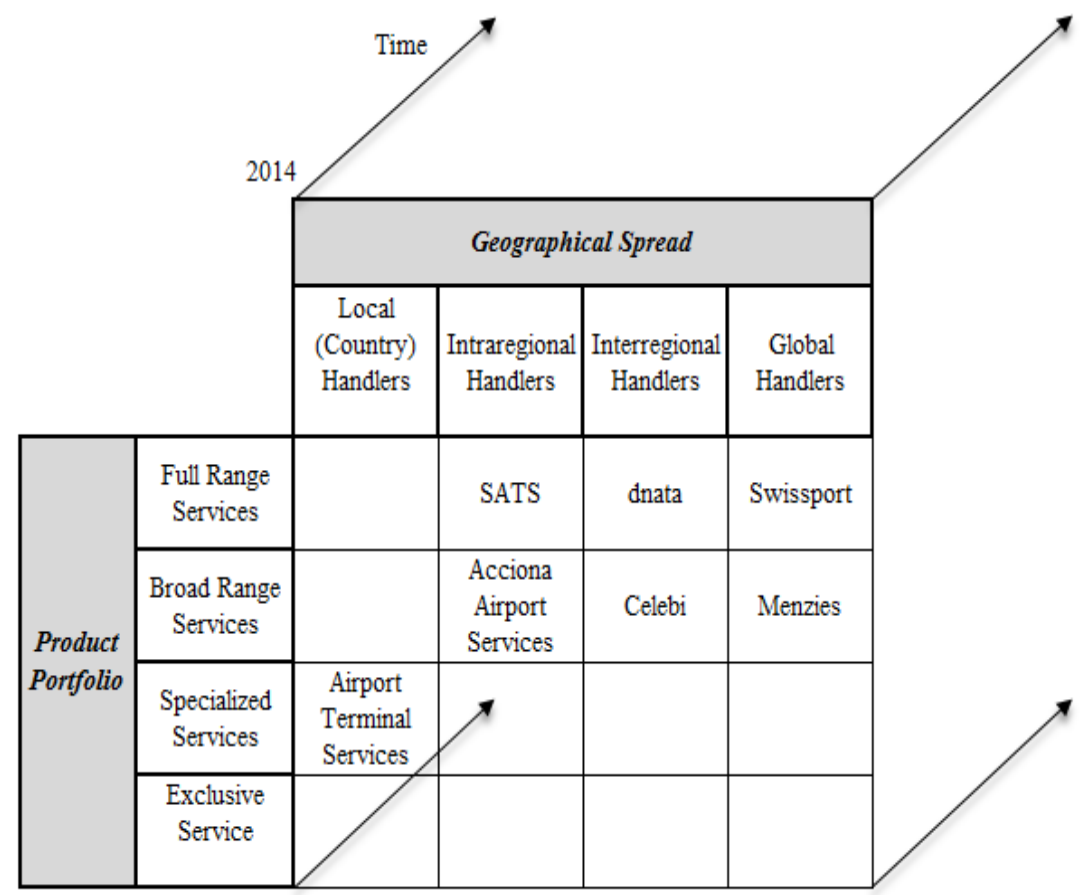

Figure 1. Analytical Grid of Airport Ground Handlers according to the Product Portfolio in the Supply and the Geographical Spread (with several 2014 examples)

Source: the authors.

Enriching the grid by the time dimension, one could research the evolution within the industry in a consistent way. We assume the shift of the industry towards multiproduct ground handling companies providing full range of services globally in future, and we argue such a shift by several examples. With regard to the organic growth (organic growth means acquisition of new ground handling operations with airlines at airports within the existing network of airports operated by handlers or the network enlargement through obtaining new licenses to operate ground handling services at more airports), Menzies Aviation acquired new ground handling operation with twenty two airlines on its network in 2013. The expansion of the Menzies network has been ensured also by acquisitions of Australian Skystar, Colombian Desacol and the UK Aero Handling and by 
the organic commencement of the operation at Windhoek in Namibia. Similarly, Swissport became the new owner of Servisair in 2013, thus creating the largest ground handling giant.

The grid we have developed would help to comprehend the international expansion strategies of ground handlers better, in particular of those with the transnational presence of their activities in world regions, and the nature of consolidation events in the industry could be described as well.

\section{Conclusions and ideas for further research}

The global nature of key players within the ground handling industry is a challenging arena for the economic aviation research. As measured with the geographical spread indices, global ground handling players are significantly present at airports in world regions, which is being achieved both by the organic growth and consolidation (mergers and acquisition). In spite of the still existing regulation of ground handling markets, we expect the evolution of the industry in the north-western direction in the grid we have designed, i.e. towards multiproduct ground handling companies with the extensive international presence in all world regions. Our expectations may be reasoned by the predicted growth of the demand for air services in the world which will generate a higher demand for ground handling services as well. Also, the new business models of airlines based on cost cutting strategies will shift the industry more towards the provision of ground handling services by independent ground handling companies. The continuing liberalisation of domestic and international air services will subsequently also boost the liberalisation and deregulation of ground handling markets which will become more accessible to the penetration on the part of independent ground handling companies.

In spite of these expectations, the current economic research of ground handling industry suffers from several problems. The data gathering problem is one of the most important ones. The industry as a whole will not have sufficient data at disposal although the industry is influenced by the activities of key players doing their business globally. We deem that just the big (global) ground handling data is inevitable not only for academic research but also policy makers in countries, as regards their regulatory decisions. As a problem in the current research we see also a lack of methodology facilitating the description of the evolution 
within the industry focusing on the global nature of the ground handling industry - an issue which so far has not been confirmed or verified although globalisation and the aviation industry have been subject to current academic research several times (Červinka, Švajdová 2011).

\section{References}

Airline Ground Services. Ground Handling Growth, 2014, http://ags-airlinegroundservices.com/previous-issues/airline-ground-services-summer-2014/handling-growth.

Müller J. et al., Restructuring of the European Ground Handling Market after the EU Market Liberalization, 2008, http://userpage.fu-lerlin.de/ jmueller/gapprojekt/ downloads/gap_papers/Groundhandling_02_02_08.pdf.

Burghouwt G. et al., Lessons Learnt from the Market for Air Freight Ground Handling at Amsterdam Airport Schiphol, "Journal of Air Transport Management" 2014, Vol. 41.

Meersman H. et al., Ground Handling in a Changing Market. The Case of Brussels Airport. Research in Transportation Business \& Management, 2011, No. 1 (1).

World Trade Organisation. Air Transport and the GATS, 2007, www.wto.org/english/ res_e/booksp_e/airtransport_2005_e.pdf.

International Civil Aviation Organisation. Airport Economics Manual. Doc 9652- third edition, 2013, www.icao.int/sustainability/documents/doc9562 en.pdf.

Aeroport Nice. Ground Handling Services, http://btob.nice.aeroport.fr/Professionals/ AIRLINES-SERVICES/Ground-Assistance/Ground-handling-categories.

ACR. Study on the Impact of Directive 96/67/EC on Ground Handling Services 1996 - 2006, Final Report, 2009, http://ec.europa.eu/transport/modes/air/studies/doc/airports/2009_02_ground_h anding.pdf.

CAPA. Airport Ground Handling - Industry Overview 2014. Part 1: Liberalisation, Efficiency \& Compensation, 2014, http://centreforaviation.com/analysis/airportground-handling--industry-overview-2014-part-1-liberalisation-efficiency--compensation-195301.

European Commission. European Commission Withdraws Amended Proposal for a Regulation on Ground Handling Services at EU Airports, 2014, www.kennedyslaw. com/article/groundhandling/.

NATA. Benefits of U.S. Model Allowing Competition Among Privately Owned Airline Service Companies over European Model of Restrictive Access, 2014, www.nata. aero/data/images/europeanairportmodelwhitepaper_000.pdf. 
Paulus N.C., Ground Handling Regulation in India, 2011, http://stanleypaulus.com/ downloads/ARP.pdf.

CAPA. Third Party Ground Handling Business in India Could Increase by \$130 Million Overnight, 2014, http://centreforaviation.com/analysis/third-party-ground-handling-business-in-india-could-increase-by-usd130-million-overnight-161630.

Results of the Public Survey on the Trade in Services Agreement, 2014, http://trade. ec.europa.eu/doclib/docs/2014/may/tradoc_152464.pdf.

Gerden E., Russia Plans to Invest Billions Into Its GSE Industry, 2014, www.aviationpros.com/article/11694451/by-eugen-gerden.

International Civil Aviation Organisation. Appendix 5: ICAO Template Air Service Agreement, 2009, www.icao.int/Meetings/AMC/MA/ICAN2009/templateairservicesagreements.pdf.

Savaser C., Ground Handling Exceptions for Foreign Air Carriers in Turkey, 2014. www. martindale.com/aviation-aerospace-law/article_2056246.htm.

United Nations Conference on Trade and Development. World Investment Report 2009: Transnational Corporations, Agricultural Production and Development, New York and Geneva, UNITED NATIONS PUBLICATION, 2009, http://unctad.org/en/pages/PublicationArchive.aspx?publicationid=743.

Červinka M. - Švajdová L., Globalization and Postglobalization Trends in Tourism and Aviation Transport, Globalizácia a jej sociálno-ekonomické Dôsledky '11 Sborník z mezinárodní vědecké konference, 2011.

Kasprzak T., Biznes i technologie informacyjne - perspektywa integracji strategicznej, Nowy Dziennik, Warszawa, 2003.

\section{PODMIOTY RYNKU OBSEUGI NAZIEMNEJ LOTNISK: NOWA TYPOLOGIA ODZWIERCIEDLAJĄCA MIĘDZYNARODOWĄ EKSPANSJĘ}

\section{Streszczenie}

W artykule przedstawiono globalny charakter niektórych graczy w branży obsługi naziemnej lotniska. W sposób kompleksowy omówiono czynniki powodujące fragmentację branży obsługi naziemnej, a to aby wyjaśnić kontekst, w którym gracze globalni rozwijają działalność na arenie międzynarodowej. Wykorzystując zmodyfikowane wersje UNCTAD Geographical Spread Indices, w artykule zbadano kilku graczy obsługi 
naziemnej oraz zaproponowano nową typologię tej obsługi, zgodną z kierunkiem ekspansji międzynarodowej: najważniejszych globalnych braczy w branży, kluczowe międzyregionalne i międzynarodowe lotniska oraz najważniejsze międzynarodowe i lokalne centra obsługi naziemnej. Uwzględniając portfel produktów, autorki artykułu tworzą jednocześnie dwuwymiarową siatkę umożliwiającą analizę ewolucji branży obsługi naziemnej w celu ukazania międzynarodowej ekspansji kluczowych zawodników w różnych usługach tej obsługi. Powołując się na wzrost organiczny oraz przykłady konsolidacji, założono rozwój branży w stronę wieloproduktowych firm obsługi naziemnej obecnych we wszystkich regionach świata.

Słowa kluczowe: obsługa naziemna, lotnisko, liberalizacja, deregulacja, zasięg geograficzny, portfel produktów, ekspansja międzynarodowa 
ZESZYTY NAUKOWE UNIWERSYTETU SZCZECIŃSKIEGO

NR 884

EKONOMICZNE PROBLEMY USŁUG NR 119

2015

DOI: 10.18276/epu.2015.119-11

\author{
Sergey Solodovnikov* \\ Olga Mazurenko**
}

\title{
THE EMPLOYMENT PROSPECTS AND THE DEVELOPMENT \\ OF THE SCIENTIFIC COMMUNITY \\ IN THE CONTEXT OF THE MODERNIZATION \\ OF THE BELARUSIAN ECONOMY
}

\begin{abstract}
The main principles of the creation of the social and scientific association while modernizing economy of the Republic of Belarus have been determined on the basis of the post-industrialization concept. They are the following: the principle of parallelism of the technical and technological modernization of economy and formation of postindustrial labor relations; the principle of labor-saving on the basis of the high technological industry; the principle of strategic orientation on the global technological tendencies; the principle of long life education of specialists; the principle of state promotion of scientific achievements into production; the principle of the growing influence of moral and ecological priorities. The necessity of forming effective information economy for creating social and scientific association has been demonstrated.
\end{abstract}

* Sergey Solodovnikov, Doctor of Economics, Full Professor, Belarus National Technical University, Faculty of Technologies of Management and Humanitarization, e-mail address: solodovnicov_s@tut.by.

** Olga Mazurenko, Master of Economics, postgraduate student, Belarus National Technical University, Faculty of Technologies of Management and Humanitarization, e-mail address: olga. maksimovna@inbox.ru. 